\title{
The PhD Advising Relationship: Needs of Returning and Direct-Pathway Students
}

\author{
Ms. Erika Mosyjowski, University of Michigan \\ Dr. Shanna R. Daly, University of Michigan
}

Shanna Daly is an Assistant Research Scientist and Adjunct Assistant Professor in the College of Engineering at the University of Michigan. She has a B.E. in Chemical Engineering from the University of Dayton and a Ph.D. in Engineering Education from Purdue University. Her research focuses on idea generation, design strategies, design ethnography, creativity instruction, and engineering practitioners who return to graduate school. She teaches design and entrepreneurship courses at the undergraduate and graduate levels. Her work is often cross-disciplinary, collaborating with colleagues from engineering, education, psychology, and industrial design.

\section{Dr. Diane L Peters, Kettering University}

Diane Peters is an Assistant Professor of Mechanical Engineering at Kettering University in Flint, MI. Her engineering education research focuses on the interaction between industry and academia.

\section{Prof. Steve Skerlos, University of Michigan}

Professor Steven J. Skerlos is Arthur F. Thurnau Professor at the University of Michigan. He is a tenured faculty member in Mechanical Engineering and Civil and Environmental Engineering. He also serves as a UM Distinguished Faculty Fellow in Sustainability.

He is Director of Sustainability Education Programs in the College of Engineering and Co-Director of the Engineering Sustainable Systems Program. He is Chief Science Officer of Fusion Coolant Systems.

Professor Skerlos has gained national recognition and press for his research and teaching in the fields of technology policy and sustainable design. He has co-founded two successful start-up companies (Accuri Cytometers and Fusion Coolant Systems), co-founded BLUElab, served as Director of the Graduate Program in Mechanical Engineering (2009-2012), and served as associate and guest editor for four different academic journals.

His Ph.D. students in the Environmental and Sustainable Technologies Laboratory have addressed sustainability challenges in the fields of systems design, technology selection, manufacturing, and water.

\section{Mr. Adam B. Baker, University of Michigan}




\section{The PhD Advising Relationship: Needs of Returning and Directing-Pathway Students}

\section{Introduction}

Though a majority of engineering $\mathrm{PhD}$ students begin their doctoral career shortly after completing an undergraduate degree (and perhaps a Master's), a significant minority of students are "returners," students who pursue a $\mathrm{PhD}$ after working outside of academia for five or more years. In the first phase of a three year NSF-funded study that aims to characterize the population of returning engineering $\mathrm{PhD}$ students, explore the interactions of their previous work experiences and their academic work, and investigate stakeholder views and institutional policies related to returning $\mathrm{PhD}$ students, we developed the nationally distributed Graduate Student Experiences and Motivations Survey (GSEMS) to compare experiences and perspectives of returners and direct-pathway students (those who progress through to the $\mathrm{PhD}$ without a 5 year or more gap). The survey included, among other topics, questions relating to students' relationships with their advisors.

The advising relationship is a critical aspect of a PhD student's experience. For both returning and direct-pathway students, advisors can have a significant effect on students' research, academic progress, feelings of support, and ultimate success. Based on data collected from both groups using the GSEMS, we examined how students described their relationships with their advisors. We report analyses of both quantitative and qualitative data, including how students assessed their advisors' effectiveness in meeting their needs in the following areas: availability to meet, management style, personal supportiveness, feedback on research, assistance with academic difficulties, and career advice, as well as other themes describing advisor relationships.

Key findings include the lack of significant differences in the ways returners and direct-pathway students report what they need from their advisors to feel supported, areas where students feel most and least supported, and emergent themes from students' open-ended responses about the advising relationship. Our work aims to contribute to a better understanding of how engineering graduate students perceive their advising experience and their advisors' effectiveness at meeting their needs. This understanding is necessary in identifying ways to improve advising to better support the needs of $\mathrm{PhD}$ students in a variety of areas.

\section{Background}

While there has been recent interest in graduate-level returners in engineering ${ }^{1,2,3,4}$, the literature is not yet extensive or fully developed. However, there is research on adult students at both the undergraduate and graduate levels. This work, combined with research on the experiences of other underrepresented groups, constitutes the major background for this work and other recent work on returners. These studies indicate that there are a number of differences between direct-pathway and returning students, both in their outlook and in their skills. Returners' outlook is characterized by strong motivation, maturity, strong teamwork skills ${ }^{5}$, a high work ethic ${ }^{6}$, and they are strongly goal-oriented ${ }^{6,7}$. While these can be advantages, returners 
also face unique challenges. They may have a different work style than many of their directpathway student peers ${ }^{8}$, lack mentoring and information relevant to the application and enrollment process in graduate school $^{6}$, and be less likely to receive fellowships and research and teaching assistantships ${ }^{9}$. With less recent practice, they may need to re-learn some of the advanced mathematics required for many courses, which places extra demands on their time ${ }^{6}$. Furthermore, they may have additional demands on their time due to family responsibilities, such as child care or care for aging parents ${ }^{9}$. Research also suggests that adult or returning students may perceive engineering programs as less welcoming to them, and feel as though they do not fit in with the overall graduate population ${ }^{8}$.

There are myriad of potential reasons returners may not feel compatible with engineering graduate programs. The advising relationship represents one potential source of support for these students transitioning back into academia. However, because the graduate student- advisor relationship is so prominent in the graduate experience, the study presented here focuses on this aspect of graduate education for both returners and direct-pathway students.

Numerous studies have documented the importance of the advising relationship for $\mathrm{PhD}$ students. The student- advisor relationship is linked to various positive graduate study outcomes, including a lower time to degree and higher completion rates. As a group, students who have a lower time to degree and higher completion rates are most likely to report a close, friendly relationship with their advisors ${ }^{10}$. Those students with a close advising relationship have also been shown to benefit from professional development and socialization opportunities and report increased interest in science and practice and demonstrate greater research self-efficacy ${ }^{11,12,13}$. Thus, as Scholsser et al. argue, "improving the overall quality of advising relationships stands to enhance the frequency of mentorships, which will, in turn, benefit both students and faculty. In addition, the general public will benefit from more mentorships via the production of more competent and confident professionals ${ }^{11}$."

There have been several studies that sought to explore the specific advisor actions or areas of support that students find most helpful. Zhao, Golde, and McCormick found a strong correlation between $\mathrm{PhD}$ student satisfaction and their advisors' academic advising behaviors, as well as advisors' personal touch and career development behaviors ${ }^{14}$. Similarly, Demb reported that students' feedback on the advising relationship centered on five critical areas:

1) Demonstrating respect for the student and valuing ideas;

2) Trust;

3) Providing challenge, feedback, direction, and conceptual support;

4) Appreciating the difference between an advisor and a mentor; and

5) Investing in the relationship by sharing personal experience while maintaining appropriate boundaries.

She identified the first three of these as core to the advising relationship, while the latter two relate to the deeper involvement of a mentoring relationship ${ }^{15}$.

Given the influence of the advising relationship on graduate student success and socialization coupled with the unique challenges many returning students face adjusting to a university environment, it is important to understand how returners perceive the support offered by their advisors and how their perceptions compare to those of direct pathway students. An 
understanding of the specific things advisors do that students find most helpful, as well as the areas students perceive to be lacking, is key to identifying the ways advisors may be better able to support student success. It is also important to explore how the advising experiences of returners and direct pathway students compare to understand the role, if any, advisors play in the unique challenges experienced by returning students and the ways in which returners utilize the support of their advisors to adapt.

\section{Methods}

\section{A. Survey Development}

The development of the GSEMS instrument was an iterative process developed based on literature and findings from a pilot project and guided by best practices of survey development. Prior to the current study, members of our team conducted an initial study that involved interviews with ten returning $\mathrm{PhD}$ students. We asked the students open-ended questions about their decisions to return to school and their experiences throughout their PhD program. This pilot work provided an initial understanding of important aspects of returners' experiences, revealed common themes, and helped identify an appropriate theoretical framework for examining the motivations and experiences of students returning for a PhD. The survey was grounded in Eccles' Expectancy Value Theory (EVT), based on a comparison of participants' open-ended responses from our earlier work about how they thought about their decision to return to graduate school which suggested EVT was a fitting model. EVT is a framework that explains how and why people make choices based on the expected results of those choices, the costs required to make a choice, and their own interests and values ${ }^{16}$. EVT was primarily used to help inform the questions included in our survey to understand student motivations to enroll and persist within a $\mathrm{PhD}$ program.

Using the EVT framework, literature on returning students and $\mathrm{PhD}$ programs, the experiences of our diverse team, and input from our advisory board, we constructed an initial draft of our survey that was refined through multiple iterations and meetings about the survey content and structure. We then piloted the survey draft with six current $\mathrm{PhD}$ students using the think-aloud cognitive interviewing technique in which participants are asked to read each question aloud and verbally describe their thought process as they answer the questions. In these pilot interviews, we consistently received feedback that there were not enough questions about the advising relationship, as students found it to be a critical aspect of their $\mathrm{PhD}$ experience that can have a huge impact on their confidence, feelings of support, success, and even retention. In response to this feedback, we decided to add an additional survey section devoted to the advising relationship and how effectively advisors meet students' needs in a variety of areas. The final categories of the GSEMS are as follows:

- Demographic Information

- Academic Background Information

- Current Academic Information

- Pre-PhD Activities / Career

- Decision to Attend Graduate School 
- Expectancy of Success in Graduate School

- Values of the PhD

- Costs of the PhD

- Cost Reduction Strategies

- Post-PhD Plans

A more comprehensive overview of the survey development process can be found in Mosyjowski, Daly, Peters, \& Skerlos ${ }^{17}$.

\section{B. Survey Distribution/Population}

The GSEMS was nationally distributed to both returning and direct pathway students. The survey was distributed electronically using Qualtrics survey software, provided by a universitywide license. Because returners are a minority of students and returner status is not a tracked demographic, survey distribution was challenging and involved screening surveys and multiple rounds of distribution in attempt to get approximately equal numbers of both returning and direct pathway students. We contacted engineering graduate programs at multiple universities and asked them to distribute the screening surveys to their domestic PhD students. We started recruitment with several universities in the Midwest and eventually expanded our efforts nationally. 31 unique institutions agreed to distribute the GSEMS to their students. We also recruited individual participants through the NSF Fellows database and peer suggestions from our survey participants.

In total, we received 476 usable survey responses from students who attended 61 different universities in 30 states. Of the 476 students, 179 of those were returners and 297 were direct pathway students. The respondents were about $34.9 \%$ female, a percentage that is higher than the national average of female doctoral students, which was $21.8 \%$ as of $2011^{18}$. Approximately $13.9 \%$ percent of the students who responded to our survey were underrepresented minorities. Respondents ranged in age from 21 to 64 with an average age of 30.4

\section{Analysis of data}

Our analysis for this paper focuses on those survey questions related to the advising relationship. The advising section of the survey asked students to assess their primary advisor's effectiveness in meeting their needs in the following areas: availability to meet, management style, personal supportiveness, feedback on research, assistance with academic difficulties, and career advice. Students were asked to rate their advisors in each of these areas on a 5-point Likert scale where $1=$ Very Ineffective and 5= Very Effective. For these questions, we calculated the overall mean and standard deviation for each category and performed t-test calculations to assess any significant differences between the ratings of returners and direct pathway students.

At the end of the advising section, we also included an open-ended question asking students "Is there anything else you would like to say about your advisor?" Of the 476 total survey participants, 138 elected to provide additional information about their advisors. These responses were analyzed qualitatively using an inductive approach, in which coding categories were developed based on emergent trends in the data. A single coder reviewed all of the open-ended 
responses, noting trends in the data. The analysis of students' open-ended responses was broken down into positive/helpful advisor qualities and negative/unhelpful qualities. Tables were created for both positive and negative qualities listing the emergent categories within each and supporting evidence from students' open-ended responses was compiled within the table. The coding scheme was then discussed and refined by the group, reviewing the trait categories and discussing the classification of student responses when needed. We identified responses from returning and direct pathway students and compared the responses within each of the advisor quality categories for any notable trends related to advisor status.

\section{Findings}

Both direct-pathway and returning graduate students assessed their advisors' effectiveness in meeting their needs somewhat positively across all six areas: availability to meet, management style, personal supportiveness, feedback on research, assistance with academic difficulties, and career advice. Mean ratings of effectiveness ranged from 3.49 to 4.04, where 3 is equivalent to "neither effective nor ineffective" and 4 is "somewhat effective." Students rated their advisors as most effective at meeting their needs related to personal support, availability to meet, and research feedback, whereas the effectiveness of advisors' management style and career advice were rated slightly less positively. The summary of responses to these Likert scale-rated questions are presented in Table 1 as a summary of all student responses as well as a division by returner and direct pathway student responses.

Table 1: Ratings of Effectiveness (Question text read: "Please rate how effectively you feel your primary advisor meets your individual needs in each of the following :")

\begin{tabular}{|ll|r|r|r|r|r|r|}
\hline & $\begin{array}{c}\text { Availability } \\
\text { to Meet }\end{array}$ & $\begin{array}{c}\text { Management } \\
\text { Style }\end{array}$ & $\begin{array}{c}\text { Personal } \\
\text { Support }\end{array}$ & $\begin{array}{c}\text { Research } \\
\text { Feedback }\end{array}$ & $\begin{array}{c}\text { Assistance } \\
\text { with } \\
\text { Academic } \\
\text { Difficulty }\end{array}$ & $\begin{array}{c}\text { Career } \\
\text { Advice }\end{array}$ \\
\hline Direct Pathway & Mean & 3.98 & 3.49 & 4 & 3.91 & 3.42 & 3.62 \\
Returner & Std. Dev. & 1.20 & 1.34 & 1.23 & 1.22 & 1.27 & 1.16 \\
& Mean & 3.99 & 3.59 & 4.1 & 3.9 & 3.61 & 3.41 \\
Combined & Std. Dev. & 1.22 & 1.31 & 1.20 & 1.19 & 1.18 & 1.19 \\
& Mean & 3.99 & 3.53 & 4.04 & 3.91 & 3.49 & 3.54 \\
& Std. Dev. & 1.21 & 1.33 & 1.22 & 1.21 & 1.24 & 1.17 \\
\hline
\end{tabular}

We ran t-tests to compare mean effectiveness ratings for each category between returners and direct pathway students. With a significance threshold of $\alpha<.05$, there were no statistically significant differences between how returning and direct pathway students evaluated their advisors effectiveness at meeting their needs in any of the six areas. The biggest non-significant ( $\alpha=.061$ and .094, respectively) differences between the groups occurred in the areas of career advice, which returners assed their advisors were less effective in meeting their needs, and assistance with academic difficulty, which returners assessed their advisors as more effective in meeting their needs than did direct pathway students. 
An analysis of students' open-ended comments about their relationships with their advisors revealed some common themes in what students identified as qualities of a positive or helpful advising relationship and qualities of a negative or unhelpful relationship with their advisors. Of the 138 open-ended responses received, 62 of those came from returners and 76 were from direct pathway students. By far the most common positive characteristic that students identified was their advisors' supportiveness, both academically and personally, many remarking that this support encouraged them and enabled them to succeed within the program. Another very common helpful trait that students commented on was that their advisor's work style was either similar to their own or that the advisor works to adapt his or her style to meet the needs of individual students. Several other positive characteristics that students identified somewhat frequently include their advisors' understanding of the importance of a work/life balance, their professional connectedness and assistance networking, acting as a mentor or role model, being easily accessible to students, and providing helpful advice. Several students even cited their advisors as being a primary factor in their decision to pursue a $\mathrm{PhD}$ in instances where the student knew his or her advisor in another capacity prior to enrolling. Additional positive characteristics of advisors mentioned by several students include that their advisors were knowledgeable, adept at securing funding and financially supporting students, and a shared interest in a research area. Table 2 below includes a comprehensive list of the positive qualities identified, a definition of each, and a selected quote from student's open-ended feedback about their advisors.

Table 2: Positive Qualities

\begin{tabular}{|c|c|c|}
\hline Trait & Description & Illustrative Quote \\
\hline Knowledgeable & $\begin{array}{l}\text { The advisor possesses a great } \\
\text { deal of content-knowledge. }\end{array}$ & "Lots of useful knowledge" (Direct Pathway (DP)) \\
\hline $\begin{array}{l}\text { Understanding of } \\
\text { work/life balance }\end{array}$ & $\begin{array}{l}\text { The advisor is } \\
\text { accommodating or } \\
\text { understanding of students' } \\
\text { non-academic } \\
\text { responsibilities. }\end{array}$ & $\begin{array}{l}\text { "My advisor appreciates my work/school balance } \\
\text { difficulties (my advisor has previous industry } \\
\text { experience). My advisor meets with me on off hours } \\
\text { and via virtual meetings (e.g. skype and google+). } \\
\text { My advisor adapts to other grad student needs as } \\
\text { well." (Returner) }\end{array}$ \\
\hline Supportive & $\begin{array}{l}\text { The advisor provides } \\
\text { academic and/or personal } \\
\text { support to his or her advisees. }\end{array}$ & $\begin{array}{l}\text { "She has been extremely supportive both } \\
\text { professionally and personally, and I have truly } \\
\text { enjoyed my experience working with her." } \\
\text { (Returner) }\end{array}$ \\
\hline $\begin{array}{l}\text { Professional } \\
\text { connectedness }\end{array}$ & $\begin{array}{l}\text { The advisor has an extensive } \\
\text { professional network that he } \\
\text { or she utilizes to students' } \\
\text { benefit and/or assists students } \\
\text { to expand their own network } \\
\text { and get connected with new } \\
\text { opportunities. }\end{array}$ & $\begin{array}{l}\text { "I am currently in the midst of my job search. } \\
\text { Through my advisor's connections, I have come } \\
\text { across several job possibilities." (DP) }\end{array}$ \\
\hline Serves as a role model & $\begin{array}{l}\text { The student looks to the } \\
\text { advisor as a professional role } \\
\text { model or successful example } \\
\text { within their field. }\end{array}$ & $\begin{array}{l}\text { "She has been a spectacular example of how one } \\
\text { navigates the odd world of academia and a gifted } \\
\text { mentor throughout graduate school." (DP) }\end{array}$ \\
\hline $\begin{array}{l}\text { Good at securing } \\
\text { funding }\end{array}$ & $\begin{array}{l}\text { The advisor is gifted at } \\
\text { securing financial support for } \\
\text { his or her research. }\end{array}$ & $\begin{array}{l}\text { "He is also very effective at acquiring funding, so I } \\
\text { have not needed to be a TA to receive pay, only a } \\
\text { research assistant." (DP) }\end{array}$ \\
\hline
\end{tabular}




\begin{tabular}{|l|l|l|}
\hline Accessible & $\begin{array}{l}\text { The advisor is readily } \\
\text { available to his or her } \\
\text { advisees. }\end{array}$ & $\begin{array}{l}\text { "He is always available and very understanding of } \\
\text { our difficulties." (DP) }\end{array}$ \\
\hline Compatible work styles & $\begin{array}{l}\text { The student feels their } \\
\text { advisor's work style is either } \\
\text { similar to or complementary } \\
\text { to their own. }\end{array}$ & $\begin{array}{l}\text { "She is great because she listens to what I need and } \\
\text { adopts her own personal style to best suit the } \\
\text { structure and deadlines that I require to perform my } \\
\text { best work." (DP) }\end{array}$ \\
\hline $\begin{array}{l}\text { Reason for pursuing a } \\
\text { PhD }\end{array}$ & $\begin{array}{l}\text { The student reports that their } \\
\text { current advisor was a primary } \\
\text { factor in his or her decision to } \\
\text { pursue a PhD. }\end{array}$ & $\begin{array}{l}\text { "My advisor is the only reason I chose to go to grad } \\
\text { school. " (Returner) }\end{array}$ \\
\hline $\begin{array}{l}\text { Shared interest in } \\
\text { research }\end{array}$ & $\begin{array}{l}\text { The student and advisor share } \\
\text { for a specific research area. }\end{array}$ & $\begin{array}{l}\text { "I think finding an advisor my first year with } \\
\text { research interests which are similar to mine has } \\
\text { really been key for me. This means that from the } \\
\text { very beginning, the research I have been doing will } \\
\text { be aligned with the dissertation topic that I } \\
\text { eventually choose." (Returner) }\end{array}$ \\
\hline Helpful advice & $\begin{array}{l}\text { The advisor provides useful } \\
\text { guidance about their } \\
\text { academic and professional } \\
\text { work. }\end{array}$ & $\begin{array}{l}\text { "He provides excellent guidance and advice on being } \\
\text { successful as an academic in general and provides } \\
\text { recommendations and support for anything I need." } \\
\text { (Returner) }\end{array}$ \\
\hline
\end{tabular}

Students' open-ended responses also revealed a number of advisors' qualities or behaviors that students found to be negative or unhelpful. The three most common concerns raised by students include 1) that they felt their advisors were ineffective managers, 2) they felt their advisors were unengaged and did not make an effort to be available to his or her advisees, or 3) they perceived their advisors were otherwise overcommitted, which suggests the advisor simply had too many other responsibilities as opposed to what students seemed to perceive as more intentionally not making time for advising. Other negative feedback included that some advisors were academically and/or personally unsupportive, had a conflicting or otherwise difficult work style, that the student and advisor struggled to communicate effectively, and that in instances where a student's work in in a different field than his or her advisor, it caused some additional difficulty. There were also several students who described ending their working relationship with at least one of their advisors due to the severity of the personal and professional difficulties between them. Other less-common concerns included advisors being too demanding and that they were unhelpful with career advice outside of a typical academic career path. A comprehensive list of negative qualities identified by students and illustrative quotes taken from the survey can be found below in Table 3 .

Table 3: Negative Qualities

\begin{tabular}{|l|l|l|}
\hline Trait & Description & Illustrative Quote \\
\hline Unavailable/unengaged & $\begin{array}{l}\text { The advisor is not engaged } \\
\text { in the student's work or is } \\
\text { otherwise unavailable or } \\
\text { difficult to get in contact } \\
\text { with. }\end{array}$ & $\begin{array}{l}\text { My current advisor has told me he does not have } \\
\text { time for me, or my research. It is not directly } \\
\text { related to him or his research area, and he doesn't } \\
\text { feel obligated to offer me time or assistance in } \\
\text { completing my degree. He has refused to meet } \\
\text { with me in person for the past } 8 \text { months. (DP) }\end{array}$ \\
\hline
\end{tabular}




\begin{tabular}{|c|c|c|}
\hline Overcommitted & $\begin{array}{l}\text { The advisor is quite busy } \\
\text { and has too many roles or } \\
\text { responsibilities. }\end{array}$ & $\begin{array}{l}\text { His time is stretched too thin - he teaches, owns a } \\
\text { business outside the university, has many research } \\
\text { areas of interest, has too many graduate students, } \\
\text { and has a family. (Returner) }\end{array}$ \\
\hline Ineffective manager & $\begin{array}{l}\text { The advisor is bad at } \\
\text { leading or managing his or } \\
\text { her students. }\end{array}$ & $\begin{array}{l}\text { Also, I know how much impact a good/effective } \\
\text { boss/manager can provide during a job. Therefore } \\
\text { since my advisor does not have any formal } \\
\text { training on how to manage students/a lab it is } \\
\text { difficult since I feel like he could benefit from } \\
\text { specific management training. (Returner) }\end{array}$ \\
\hline Too demanding & $\begin{array}{l}\text { The advisor has unrealistic } \\
\text { work expectations of his or } \\
\text { her students and places too } \\
\text { high of demands on them. }\end{array}$ & $\begin{array}{l}\text { His quest for higher impact factor, fame and } \\
\text { fortune have stagnated the production of his } \\
\text { students. His students are driven to work by guilt } \\
\text { that they aren't working hard enough. As a result, } \\
\text { most have lost focus and hope that they will at } \\
\text { least graduate with more than } 1 \text { publication after } \\
\text { 5+ years. (Returner) }\end{array}$ \\
\hline $\begin{array}{l}\text { Relationship ended out of } \\
\text { negativity }\end{array}$ & $\begin{array}{l}\text { The student reported } \\
\text { terminating their } \\
\text { relationship with an advisor } \\
\text { after it became too negative } \\
\text { to sustain. }\end{array}$ & $\begin{array}{l}\text { I have a new advisor; my previous advisor was } \\
\text { very abusive and detrimental to my self- } \\
\text { confidence and my belief in my abilities to } \\
\text { continue in the program. I switched advisors, and } \\
\text { my department reprimanded my previous advisor. } \\
\text { (DP) }\end{array}$ \\
\hline Conflicting work styles & $\begin{array}{l}\text { The advisor has a different } \\
\text { work style than the student } \\
\text { which leads to difficulty } \\
\text { working together. }\end{array}$ & $\begin{array}{l}\text { I think as a person coming from the work force, I } \\
\text { need more structure and feedback. My advisor has } \\
\text { always been in academia and does not like } \\
\text { structure and anything that resembles } \\
\text { confrontation. He doesn't quite understand that not } \\
\text { all his students thrive under the "hands-off" } \\
\text { approach that he thrives under. (Returner) }\end{array}$ \\
\hline Unsupportive & $\begin{array}{l}\text { The advisor does not } \\
\text { provide advisees with } \\
\text { academic and/or personal } \\
\text { support. }\end{array}$ & $\begin{array}{l}\text { I feel as though my advisor doesn't support me } \\
\text { academically and in fact makes work life tougher. } \\
\text { (DP) }\end{array}$ \\
\hline $\begin{array}{l}\text { Unhelpful with non- } \\
\text { academic career advice }\end{array}$ & $\begin{array}{l}\text { The advisor's own academic } \\
\text { orientation makes it difficult } \\
\text { for him or her to provide } \\
\text { advice about non-academic } \\
\text { career paths or may not } \\
\text { understand or support a } \\
\text { student's choice to pursue a } \\
\text { career outside of academia. }\end{array}$ & $\begin{array}{l}\text { Generally unhelpful with career advice because, as } \\
\text { a stereotypical academic, he assumed EVERY one } \\
\text { of his students wanted to follow a career path } \\
\text { identical to his (PhD -> postdoc -> start their own } \\
\text { lab as tenure-track junior faculty). He was always } \\
\text { baffled by the concept that some students didn't } \\
\text { want to go into academia, and this made } \\
\text { discussions of other career options with him rather } \\
\text { difficult or pointless. (DP) }\end{array}$ \\
\hline $\begin{array}{l}\text { Advisor in unrelated field } \\
\text { adds difficulty }\end{array}$ & $\begin{array}{l}\text { The student has an advisor } \\
\text { in a discipline different from } \\
\text { their own and is thus less } \\
\text { able to advise them in } \\
\text { discipline-specific matters. }\end{array}$ & $\begin{array}{l}\text { I chose an advisor from a department different } \\
\text { than mine. This makes my work more difficult as } \\
\text { I have to teach him and he advises the general } \\
\text { work and guides me on who to speak with. } \\
\text { (Returner) }\end{array}$ \\
\hline Communication difficulties & $\begin{array}{l}\text { The student and advisor } \\
\text { have a difficult time } \\
\text { establishing effective } \\
\text { communication. }\end{array}$ & $\begin{array}{l}\text { We just can't establish proper communication. We } \\
\text { are both very frustrated and this generates my } \\
\text { doubts when it comes to my success. (Returner) }\end{array}$ \\
\hline
\end{tabular}


Returners and direct pathway students voiced many of the same opinions regarding the qualities that characterized both positive and negative advising relationships, which is largely consistent with the quantitative findings that revealed no significant differences between the groups' ratings of their advisors' effectiveness. However, there were several interesting trends in students' openended responses. A disproportionate number of direct-pathway students mentioned an appreciation for their advisors' assistance networking and for those that serve as a professional mentor, which could possibly reflect returners' higher likelihood of having past experience within the field and existing professional connections. There were also interesting trends in some of the negative characteristics identified by students. Returners were much more likely to specifically critique their advisors' management style, whereas direct-pathway students more frequently asserted that their advisors were difficult to work with or had conflicting work styles. It seems likely that returners' past industry experience influences their perception on the impact of leadership ability and in fact, several returning students directly cited their past experience when providing this critique of their advisors: "I would rate my advisor as extremely ineffective most of the time. Fortunately I have management experience and maturity to make up this deficit." Additionally, while returners may recognize the importance of leadership ability, they may also have more experience working with a variety of people and different work styles. Interestingly, direct-pathway students were the only ones to comment (at least in their openended responses) that they had to terminate their working relationship with their advisor due to negativity, which could be due to a number of factors, including the possibility that returners may feel more pressure to complete their degrees without interruption, or that returners may be better prepared to manage difficult personal relationships in their work.

\section{Discussion}

Overall, the engineering PhD students in our study assessed their advisors somewhat positively. On average students assessed their advisors as more effective than ineffective at meeting their needs in a variety of areas. Additionally, many students specifically cited their advisors' personal and academic supportiveness when given the opportunity to provide open-ended feedback. Participant responses did suggest there is some room for improved communication between advisors and their students, however. Many of the most common concerns identified by students related to their perceptions of advisor availability and the frequency and quality of communication. While there are certainly a variety of personal circumstances, this may in part reflect the challenge students face adjusting to the more independent nature of a PhD program coupled with faculty's numerous responsibilities. This suggests a need for communication strategies that enable advisors to make their students feel supported within a realistically limited amount of time.

The lack of significant differences in how returners and direct-pathway students evaluated their advisors' effectiveness in meeting their needs in a variety of areas was quite surprising in the context of the larger study. Our analysis of the survey results revealed fairly strong patterns of differences in many other areas including the perceived costs and values of pursuing a $\mathrm{PhD}$, which will be discussed in further detail in coming work. Given this pattern throughout many of 
the other areas of analysis, the lack of significant differences in students' reported experiences related to the advising relationship is notable. It also raises questions about what possible impact advisors could have on other areas of students' $\mathrm{PhD}$ experience where significant differences are evident.

There are multiple components of students' academic experience and while the advising relationship is an important one, there is little that stands out in this study to suggest that the advising relationship is a unique source of stress or difference in the experiences of returning students. If indeed faculty's treatment of both returners and direct pathway students is equitable, yet other work suggests returners face unique challenges, it is perhaps worth considering how advisors could better tailor their interaction with returning students to provide more targeted, beneficial support. Overall returners (as well as direct pathway students) report having a fairly supportive advising relationship and provided positive feedback on their advisors' personal and academic supportiveness and respect for work life balance, all of which have the potential to be a positive factor in light of returner's unique challenges such as increased family responsibilities and other demands on their time ${ }^{9}$. Further exploration about the specific areas of challenge faced by returners is needed to understand how advisors might better support students, an area we plan to examine in our coming analyses.

There are several parallels between the supportive characteristics and actions identified by students in our study and the five broad areas of feedback on the advising relationship identified by Demb ${ }^{15}$. Two of the main advising components described by Demb related to the interpersonal relationship between students and their advisors: 1) demonstrating respect and valuing students' ideas and 2) trust. The students who participated in our study also frequently cited characteristics of their personal relationship with their advisors, though our analysis focused on more specific characteristics such as personal supportiveness, and respect for worklife balance. Demb's work identified a third critical area of the advising relationship related to more practical, academic support and guidance: providing challenge, feedback, direction, and conceptual support. Again, our work identified several characteristics cited by students related to this practical and academic support, including their advisors' helpful advice, research feedback, and professional guidance. Furthermore, many of the concerns raised by students related to a lack of this practical, academic support either relating to the manner in which their advisors try to manage or guide their students or difficulties relating to the amount and quality of communication and feedback. Demb's work also drew a distinction between the advising relationship versus the more involved personal relationship of that with a mentor. Though several students in our study did specifically mention their advisors serving as a mentor or role model, the distinction between advisors and mentors was not a topic commonly raised by students in their open-ended responses in our survey, quite possibly due to the focus of the questions specifically on students' relationships with their primary advisors.

The results of this study are not generalizable to all engineering PhD students due to our targeted recruiting and sampling approach. The focus of the survey was not on the advising relationship, it was just one aspect of a much larger study exploring the PhD experiences of and motivations of returning and direct-pathway students and therefore included a limited number of quantitative 
questions and only one very open-ended question with no specific qualitative questions digging deeper into the advising relationship which could provide more detailed, targeted data. Given the relatively narrow scope of the advising-related questions, we are not able to directly assess the impact of the advising relationship on various measures of student success. Our future plans include the analysis of the larger survey to better understand returners' decisions to pursue a $\mathrm{PhD}$, the unique challenges they face, and coping strategies they utilize and how these compare to those of direct pathway students. We also conducted in-depth interviews with 53 returning and direct pathway students from across the country and plan to analyze that data for a better understanding of the development of students' research and how their past experiences influence their PhD work. Finally, we will conduct focus groups with various stakeholders in industry, government, and academia, including faculty advisors, to better understand their perceptions on the roles returners can and do play.

\section{References}

1. Peters, D. L. \& Daly, S.R. (2011). The challenges of returning: Transitioning from an engineering career to graduate school. American Society of Engineering Education Annual Conference \& Exposition, Vancouver, BC.

2. Peters, D. L. \& Daly, S. R. (2012). Why do professionals return to school for graduate degrees? Proceedings of the American Society of Engineering Education Annual Conference \& Exposition, San Antonio, TX.

3. Peters \& Daly, (2013). Returning to graduate school: Expectations of success, values of the degree, and managing the costs. Journal of Engineering Education.

4. Strutz, M. L., Cawthorne Jr., J.E., Ferguson, D. M, Carnes, M.T. \& Ohland, M.W. (2011). "Returning Students in Engineering Education: Making a Case for 'Experience Capital."” American Society of Engineering Education Annual Conference \& Exposition, Vancouver, BC.

5. Hofinger, R. J. and Feldmann, L. J. (2001). The role of the adult student in the classroom. American Society for Engineering Education Annual Conference \& Exposition, Albuquerque, NM.

6. Prusak, Z. (1999). Learning environment in engineering technology with a high percentage of non-traditional Students. American Society of Engineering Education Annual Conference \& Exposition, Charlotte, NC.

7. MacFadgen, L. (2008). Mature students in the persistence puzzle: An exploration of the factors that contribute to mature students' health, learning, and retention in post-secondary education. Canadian Council on Learning.

8. Schilling, W. (2008). Issues effecting doctoral students returning to engineering education following extensive industrial experience. American Society for Engineering Education Annual Conference \& Exposition, Pittsburgh, PA.

9. Nettles, M. \& Millett, C. (2006). Three magic letters: Getting to Ph.D. Baltimore, MD: Johns Hopkins University Press.

10. De Valero, Y. F. (2001). Departmental Factors Affecting Time-to-Degree and Completion Rates of Doctoral Students at One Land-Grant Research Institution. The Journal of Higher Education, 72(3), 341.

11. Schlosser, L. Z., Lyons, H. Z., Talleyrand, R. M., Kim, B. S. K., \& Johnson, W. B. (2010). Advisor-Advisee Relationships in Graduate Training Programs. Journal of Career Development, 38(1), 3-18.

12. Schlosser, L. Z., \& Gelso, C. J. (2001). Measuring the working alliance in advisor-advisee relationships in graduate school. Journal of Counseling Psychology, 48, 157-167.

13. Schlosser, L. Z. \& Kahn, J. H. (2007). Dyadic perspectives on advisor-advisee relationships in counseling psychology doctoral programs. Journal of Counseling Psychology, 54, 211-217.

14. Zhao, C., Golde, C. M., \& McCormick, A. C. (2007). More than a signature: how advisor choice and advisor behaviour affect doctoral student satisfaction. Journal of Further and Higher Education, 31(3), 263-281. 
15. Demb, A. (2012). Daring the doctorate: the journey at mid-career. Lanham, Md. Rowman-Littlefield Publishers.

16. Eccles, J. S., B. L. Barber, K. Updegraff, and K. M. O’Brien (1998). An expectancy-value model of achievement choices: The role of ability self-concepts, perceived task utility and interest in predicting activity choice and course enrollment. In L. Hoffmann, A. Krapp, K. A. Renninger, \& J. Baumert (Eds.), Interest and learning: Proceedings of the Seeon Conference on Interest and Gender (pp. 267-279), Institute for Science Education at the University of Kiel: IPN.

17. Mosyjowski, E. A., Daly, S.R., Peters D.L., \& Skerlos, S.J. (2013). Designing a Survey Instrument for a National Study of Direct-pathway and Returning Engineering Graduate Students. American Society of Engineering Education Annual Conference \& Exposition, Atlanta, GA.

18. Yoder, B.L. (2011) Engineering by the Numbers. http://www.asee.org/ 